\title{
Physico-chemical characteristics, antibacterial, and antioxidant activities of genuine forest honey from East Kalimantan
}

\author{
${ }^{1}$ Prayitno, Y.A., ${ }^{1,2}$ Emmawati, A. and ${ }^{2,3 * * R a h m a d i, ~ A . ~}$ \\ ${ }^{1}$ Humid Tropical Agriculture Postgraduate Program, Faculty of Agriculture, Mulawarman University, \\ Samarinda, Indonesia \\ ${ }^{2}$ Department of Agricultural Products Technology, Faculty of Agriculture, Mulawarman University, \\ Samarinda, Indonesia \\ ${ }^{3}$ Center of Excellence for Tropical Studies, Mulawarman University, Samarinda, Indonesia
}

Article history:

Received: 18 May 2020

Received in revised form: 10

June 2020

Accepted: 4 July 2020

Available Online: 7 August 2020

Keywords:

Forest honey profile,

Antibacterial,

Antioxidant,

Immunostimulant,

East Kalimantan

DOI:

https://doi.org/10.26656/fr.2017.4(6).235

\begin{abstract}
In the dense tropical forests of Kalimantan, Apis dorsata produces forest honey with pollen diversity that has the potential to have unique antibacterial and antioxidant properties. This study is aimed to report the physicochemical characteristics, antioxidant activity and antibacterial analysis of forest honey from East Kalimantan. A total of nine samples of forest honey were purchased from local buyers of several regions. The power of hydrogen $(\mathrm{pH})$, water content, diastase enzymes, fructose levels, and glucose levels were measured. Antioxidant activity was measured with ABTS assay. Antibacterial activity was conducted against Staphylococcus aureus, Bacillus cereus, Escherichia coli, and S. enterica serovar Typhi. Fourier Transform Infra-Red (FTIR) identified antibacterial functional groups. Honey samples from tropical forests in East Kalimantan had $\mathrm{pH}$ between $2.93 \pm 0.06$ and $3.83 \pm 0.06$, a moisture content between $18.44 \pm 0.64$ and $25.67 \pm 0.29 \%$, fructose levels between $7.85 \pm 0.05$ and $17.73 \pm 0.13 \%$, and glucose levels between $1.24 \pm 0.16$ and $17.34 \pm 0.14 \%$. Goa Tembenus honey showed the highest $\mathrm{IC}_{50}$ antioxidant activity and the highest Diastase Enzyme activity. Goa Tembenus and Bongan honey showed good antibacterial activity against Gram-positive and Gram-negative. Minimum inhibitory levels of honey were found at concentrations of $25 \%$ and $30 \%$. Honey from tropical forests in East Kalimantan has $\mathrm{H}_{2} \mathrm{O}_{2}$ as an antibacterial component.
\end{abstract}

\section{Introduction}

Forest honey, harvested from Apis dorsata bee, has the potential as a source of micro-nutrition, i.e., antioxidant (Tuksitha et al., 2018). The honey-producing areas in East Kalimantan are mainly located in the Berau and Paser districts (Muslim, 2014). Forest-based honey potentials were also identified in several other regions in East Kalimantan, such as North Penajam Paser Regency, Kutai Kertanegara Regency, and West Kutai Regency. Forest bee host trees, namely Banggeris (Kompassia excelsa), are scattered in the forests of East Kalimantan (Muslim, 2014). However, forest honey in East Kalimantan, in general, is still not well populated and maintained, due to several factors such as the maintenance of $A$. dorsata, the timely journey to harvest honey, and the difficulty of accessing the location of honeybee hives in a deep jungle. Forest honey differs in the source of pollens obtained, final product thickness, and apparent color (Sofia et al., 2017; Tanleque-Alberto et al., 2019). The forests of East Kalimantan have the characteristics of humid tropical forests and have various types of tropical plants. The advantages of forest honey from East Kalimantan are in terms of taste, color, and purity (Muslim, 2014; Da Silva et al., 2016; Wulandari, 2017).

However, one of the weaknesses of forest honey is standardization. Forest honey is prone to be falsified by irresponsible parties to gain excess profits (Rachmawaty, 2011; Adalina, 2017). This research seeks to support the identification and authentication of forest honey produced in East Kalimantan. The purity parameters of honey may consist of physicochemical properties, sugar contents, antioxidant and antibacterial activities, and diastase enzyme activity (Rahman et al., 2013; Da Silva et al., 2016; Heard et al., 2017).

The purpose of this research was to determine the physicochemical characteristics, antioxidant activity, 
antibacterial, and functional group analysis. The observations included $\mathrm{pH}$, water content, diastase enzyme activity, sugar content, antioxidant activity, antibacterial activity against four bacteria, and functional group analysis.

\section{Materials and methods}

\subsection{Samples and materials}

Nine forest honey samples were directly purchased from harvesters between $1^{\text {st }}$ and $20^{\text {th }}$ July 2019 in several regions in East Kalimantan, consisting of Goa Parung Honey (MP1), Goa Tembenus Honey (MT2), ICHI Conservative Honey (MI3), Muara Lawa Honey (ML4), Bongan Honey (MB5), Long Bagun Honey (MLB6), Bukit Bengkirai Honey (MBB7), Muara Bengkal Honey (MMU8), Lebak Cilong Honey (MLC9). Commercial honey (MK) was separately purchased (HNI, Indonesia). All honey samples were preserved in a dark room at ambient temperature $\left(25 \pm 3^{\circ} \mathrm{C}\right)$ before being analyzed.

Two Gram-positive strains of $S$. aureus and $B$. cereus and two Gram-negative strains of Escherichia coli ATCC 35218 and S. enterica serovar Typhi ATCC 140281 were obtained from the Faculty of Medicine, Faculty of Pharmacy, Faculty of Agriculture, and Laboratory of Agricultural Microbiology at Mulawarman University. Chemical materials were purchased, including Mueller Hinton Agar (MHA) (Merck, USA), Nutrient agar (Merck, USA), Nutrient Broth (Merck, USA), sodium chloride ( $\mathrm{NaCl}$ ) solution (Merck, USA), sterile distilled water, Anthrone (Merck, USA), sodium oxalate (Merck, USA), calcium carbonate $\left(\mathrm{CaCO}_{3}\right)$ (Merck, USA), fructose (Pudak, Indonesia), glucose (Pudak, Indonesia), Pb-acetate (Pudak, Indonesia), 70\% ethanol (PIM Pharmaceuticals, Indonesia), absolute ethanol (Merck), $\mathrm{FeCl}_{3}$ (Merck), $\mathrm{H}_{2} \mathrm{SO}_{4}$ (Merck), $\mathrm{HCl} 2$ $\mathrm{N}$ (Merck), $\mathrm{K}_{2} \mathrm{~S}_{2} \mathrm{O}_{8}$ (Merck, USA), ABTS (Sigma Aldrich, USA), ethanol pa (Fulltime, China), and vitamin C (Sigma Aldrich, USA).

The tools used were UV-VIS Spectrophotometry (Eppendorf, Germany), FTIR Spectrophotometer (Thermo Scientific Nicolet IS10, Madison, WI), incubators (Memmert), autoclaves (Hirayama), ovens (Binders), pH meters (Hanna), scales (Hanna), Mettler Toledo), hotplate (Thermoline), vortex (Thermoline), micropipette (Transferpette), water bath (Memmert), and glassware.

\subsection{Statistical analysis}

This research was conducted with the Purposive Sampling method, involving nine forest honey from various places in East Kalimantan, Indonesia. Each sample was tested in triplicate. Average measurement and standard deviation were recorded before nonfactorial ANOVA was conducted. Fisher Least Significant Difference was used at alpha $(\alpha)$ equaled $5 \%$.

\section{$2.3 \mathrm{pH}$ and water content}

Honey $\mathrm{pH}$ measurement was done using a Mettler Toledo $\mathrm{pH}$ meter. The instrument was calibrated using a standard solution of $\mathrm{pH} 4.00$ and 7.00, and the water content in the sample was measured by the gravimetric method, according to Sudarmadji et al. (2010).

\subsection{Sugar levels}

Anthrone Reagent Method was used to measure sugar levels (Sartika, 2011). Honey sample carefully weighted at $14.5 \mathrm{~g}$ and added with $100-200 \mathrm{~mL}$ of water and $1 \mathrm{~g}$ of $\mathrm{CaCO}_{3}$. The solution was boiled for 30 mins. During boiling, water was added so that the volume remains the same. After chilling at ambient temperature $\left(25 \pm 3^{\circ} \mathrm{C}\right)$, the addition of a 3 to $5 \mathrm{~mL} \mathrm{~Pb}$-acetate solution was conducted until the solution became clear. After filtration of the solution with Whatman filter paper No. 2 , sodium oxalate $1 \mathrm{~g}$ was added. About $0.1 \%$ Anthrone reagents were prepared by dissolving $1 \mathrm{~g}$ Anthrone in concentrated $\mathrm{H}_{2} \mathrm{SO}_{4}$ until the volume reached $50 \mathrm{~mL}$. Glucose and fructose standard solutions were made by weighing $200 \mathrm{mg}$ of glucose and fructose in $100 \mathrm{~mL}$ of distilled water taken $10 \mathrm{~mL}$ diluted to $100 \mathrm{~mL}$. Preparation of a standard curve was carried out employing a standard solution of glucose and fructose pipetted into a test tube 0.0 (blank), 0.2, 0.4, 0.6, 0.8, 1.0 $\mathrm{mL}$. Each solution was added with $5 \mathrm{~mL}$ of Anthrone reagents, heated at $100^{\circ} \mathrm{C}$ for 12 mins, then the absorbance was read at the maximum wavelength, and interpolation was conducted.

\subsection{Antioxidant activity}

ABTS method was used to measure the antioxidant activity (Salampe, 2019). Samples were taken as much as $20 \mu \mathrm{L}, 30 \mu \mathrm{L}, 40 \mu \mathrm{L}, 50 \mu \mathrm{L}$, and $60 \mu \mathrm{L}$. To each sample, $1 \mathrm{~mL}$ of ABTS solution (2,2-Azinobis (3- ethyl benzothiazoline)-6-sulfonic acid) was added and diluted to reach a volume of $5 \mathrm{~mL}$ with absolute ethanol (Fulltime, China). The final sample concentration was $100 \mathrm{ppm}, 150 \mathrm{ppm}, 200 \mathrm{ppm}, 250 \mathrm{ppm}$, and $300 \mathrm{ppm}$. As a standard, a vitamin $\mathrm{C}$ stock solution was set at 200 ppm. Furthermore, from the stock solution each taken $200 \mu \mathrm{L}, 250 \mu \mathrm{L}, 300 \mu \mathrm{L}, 350 \mu \mathrm{L}$, and $400 \mu \mathrm{L}$, added with $1 \mathrm{~mL}$ of ABTS solution, then diluted to a volume of $5 \mathrm{~mL}$ with ethanol absolute (Fulltime, China) to obtain a concentration of one ppm, $1.25 \mathrm{ppm}, 1.5 \mathrm{ppm}, 1.75 \mathrm{ppm}$, and two ppm. The absorbance of samples and standards was measured by UV-Vis spectrophotometry at a wavelength of $752 \mathrm{~nm}$. 


\subsection{Diastase enzyme activity}

The method used refers to a standardized method (SNI 3545: 2013). Honey was taken $10 \mathrm{~mL}$ mixed with 5 $\mathrm{mL}$ of starch solution in a test tube heated with a water bath at $40 \pm 2^{\circ} \mathrm{C}$ for 15 mins. At each 5 minute intervals, 1 $\mathrm{mL}$ of the mixture was taken, and $10 \mathrm{~mL}$ of iodine solution was added. The remaining mixture was then added to water until it reaches the initial volume. Absorbance was read at a wavelength of $660 \mathrm{~nm}$. Repetition of the treatment was carried out until it reaches to an $\mathrm{A}$ value $<0.235$. The results obtained were plotted to obtain the absorbance value curve with time (mins). The simple formula for measuring $\mathrm{DN}$ was $\mathrm{DN}=$ 300/t, where DN was the value of the Diastase Enzyme activity, and ' $\mathrm{t}$ ' was the time required until the Absorbance value was reached $<0.235$ (A).

\subsection{Antibacterial activity}

This method refers to previous research (Astrini, 2014). Each strain inoculum was resuspended at $35^{\circ} \mathrm{C}$ in sloped agar. One loop of the bacteria was put into the Nutrient Broth in a test tube, then was incubated for 24 hrs at $37^{\circ} \mathrm{C}$. Bacterial concentrations were adjusted to $0.510^{-7} \mathrm{CFU} / \mathrm{mL}$ with MacFarland Standard Solution. Media Mueller Hilton agar (MHA) was prepared on a petri dish, and then wells were made with a diameter of 6 $\mathrm{mm}$. Each well was dripped with honey as much as 50 $\mu \mathrm{L}$. The negative control used was $0.9 \% \mathrm{NaCl}$, while chloramphenicol $30 \mu \mathrm{g} / \mathrm{mL}$ was used as a positive control. The Petri dishes were incubated for $24 \mathrm{hrs}$ at a temperature of $37^{\circ} \mathrm{C}$.

\subsubsection{Minimum inhibitory concentration (MIC)}

Forest Honey Minimum Inhibitory Level showed the lowest concentration of honey that inhibited Grampositive and negative bacteria at a concentration of $1 \mathrm{x}$ $10^{7} \mathrm{CFU} / \mathrm{mL}$. The concentration of honey used was $25 \%$, $30 \%, 35 \%$, and $40 \%$.

\subsection{Functional group analysis with FTIR}

Irnawati (2020) method was used to determine the FTIR spectrum of the samples. The FTIR (Thermo Scientific Nicolet IS10, Madison, WI) instrument was controlled with OMNIC (Thermo Scientific) software. Honey samples were dropped on the FTIR sample site and then measured. The sampling technique used was horizontal attenuated total reflectance (HATR) using $\mathrm{ZnSe}$ crystal. Each sample was scanned three times at a resolution of $8 \mathrm{~cm}^{-1}$ at wavenumbers between 4000 and $650 \mathrm{~cm}^{-1}$. Then, the spectrum obtained was recorded as absorbance values at each data point.

\section{Results and discussion}

Forest honey was obtained from traditional harvesters originating from nine areas in three districts in East Kalimantan. The acquisition price for each honey was varied, ranging between 100 and 200 thousand rupiahs per liter. All honey samples were obtained directly from the honey harvesters. It is a common belief in the community that the honey purchased from the local seller was genuine. The price of forest honey was relatively higher than commercial honey on the market because of more properties and unique harvesting. Other factors that make the price of forest honey expensive were that the manual harvesting process and the long journey in a deep jungle to harvest the honey (Sofia et al., 2017).

\section{$3.1 \mathrm{pH}$ value}

The $\mathrm{pH}$ value ranged between $2.93 \pm 0.06$ and $3.83 \pm 0.06$ (table 1). The highest value was obtained from MK honey (3.83 \pm 0.06$)$, and the lowest value was from MMU8 honey $(2.93 \pm 0.06)$. Each type of honey had a different $\mathrm{pH}$ value. This was caused by environmental factors and various types of food and nest conditions. (Yesserie, 2015) Manuka and Tenerife honey have the same $\mathrm{pH}$ as in this study. Both honey were more acidic than other types of honey, as reported earlier (Bentabol Manzanares et al., 2014; Deng et al., 2018). The acidic nature of honey could affect antimicrobial activity and might have an essential role in the shelf life of honey (Mandal et al., 2010).

\subsection{Water content}

Honey content ranged from $18.44 \%$ to $25.67 \%$ (Table 1), while the honey SNI requirement is at a maximum of $22 \%$ (SNI 3545: 2013). The water contents of Honey MT2, MI3, ML4, MB5, MLB6, MBB7, MMU8, and MLC9 were higher than SNI requirements. Forest honey had a reasonably high water content due to the nature of a humid, tropical forest area with high rainfall. This statement was in line with Bogdanov (2011), stating that honey has hygroscopic properties. So, when harvesting forest honey in the morning, there will be indirect absorption of water vapor from the surrounding environment. The absorption of water vapor by honey occurs continuously until the packaging stage. The water content value of Kalimantan forest honey reported in this study was almost the same as other forest honey, 19.2\% (Alzahrani et al., 2012). Other studies indicated lower honey water levels, $11.59 \pm 0.12 \%$ (Moniruzzaman et al., 2013).

\subsection{Diastase enzyme activity}

The minimum activity of the enzyme diastase in 
Table. 1 Physicochemical property of Forest Honey in East Kalimantan

\begin{tabular}{ccccccc}
\hline Honey & $\mathrm{pH}$ & Moisture $(\%)$ & Fructose $(\%)$ & Glucose $(\%)$ & $\mathrm{IC}_{50}(\mathrm{ppm})$ & Diastase Number $(\mathrm{DN})$ \\
\hline MP1 & $3.63 \pm 0.06^{\mathrm{b}}$ & $20.39 \pm 0.20^{\mathrm{c}}$ & $7.85 \pm 0.05^{\mathrm{i}}$ & $3.73 \pm 0.22^{\mathrm{f}}$ & $177.25 \pm 0.88$ & 17.65 \\
MT2 & $3.33 \pm 0.06^{\mathrm{cd}}$ & $22.42 \pm 0.35^{\mathrm{b}}$ & $14.61 \pm 0.08^{\mathrm{c}}$ & $15.43 \pm 0.08^{\mathrm{c}}$ & $117.46 \pm 0.40$ & 21.43 \\
MI3 & $3.20 \pm 0.10^{\mathrm{e}}$ & $22.13 \pm 0.88^{\mathrm{b}}$ & $17.73 \pm 0.13^{\mathrm{b}}$ & $17.34 \pm 0.14^{\mathrm{b}}$ & $395.69 \pm 2.20$ & 14.29 \\
ML4 & $3.37 \pm 0.06^{\mathrm{c}}$ & $23.00 \pm 0.63^{\mathrm{b}}$ & $13.46 \pm 0.08^{\mathrm{d}}$ & $12.97 \pm 0.11^{\mathrm{d}}$ & $404.75 \pm 2.26$ & 13.64 \\
MB5 & $3.03 \pm 0.06^{\mathrm{f}}$ & $22.59 \pm 1.40^{\mathrm{b}}$ & $11.18 \pm 0.14^{\mathrm{f}}$ & $7.52 \pm 0.24^{\mathrm{e}}$ & $371.35 \pm 2.46$ & 10.71 \\
MLB6 & $3.03 \pm 0.06^{\mathrm{f}}$ & $23.16 \pm 0.30^{\mathrm{b}}$ & $8.77 \pm 0.22^{\mathrm{g}}$ & $2.80 \pm 0.11^{\mathrm{g}}$ & $395.72 \pm 1.60$ & 13.04 \\
MBB7 & $3.23 \pm 0.06^{\mathrm{de}}$ & $25.67 \pm 0.29^{\mathrm{a}}$ & $8.30 \pm 0.18^{\mathrm{h}}$ & $1.45 \pm 0.05^{\mathrm{h}}$ & $538.77 \pm 0.94$ & 17.65 \\
MMU8 & $2.93 \pm 0.06^{\mathrm{f}}$ & $25.63 \pm 0.65^{\mathrm{a}}$ & $8.36 \pm 0.10^{\mathrm{h}}$ & $1.24 \pm 0.16^{\mathrm{i}}$ & $214.01 \pm 0.24$ & 15.79 \\
MLC9 & $3.30 \pm 0.10^{\text {cde }}$ & $25.44 \pm 1.13^{\mathrm{a}}$ & $12.37 \pm 0.12^{\mathrm{e}}$ & $7.39 \pm 0.05^{\mathrm{e}}$ & $250.52 \pm 0.83$ & 12.5 \\
MK & $3.83 \pm 0.06^{\mathrm{a}}$ & $18.44 \pm 0.64^{\mathrm{d}}$ & $20.63 \pm 0.20^{\mathrm{a}}$ & $18.67 \pm 0.21^{\mathrm{a}}$ & $584.13 \pm 3.20$ & 13.04 \\
\hline
\end{tabular}

Values expressed as mean $\pm \mathrm{SD}(\mathrm{n}=3)$. Numbers on the same row followed by the same letter indicate no significant difference in the LSD test at the $\alpha$ level of $5 \%$.

honey is three and is expressed by the diastase number (DN) (SNI 3545: 2013). DN on the Schade scale means total grams of starch hydrolyzed in $1 \mathrm{hr}$ at $40^{\circ} \mathrm{C}$ per 100 g honey (Codex Alimentarius Commission, 2001) Levels of diastase enzymes from Forests in East Kalimantan ranged between 10.71 and $21.43 \mathrm{DN}$. This value is above the minimum amount that has been set (SNI 3545: 2013). The lowest diastase enzyme activity was in MB5 forest honey, while the highest DN was in MT2 honey (Table 1) Diastase enzymes are formed during the process of maturation of honey. This enzyme is only found in pure honey or fresh honey. In other studies, the DN values of multiflora honey samples from Santa $\mathrm{Fe}$ province of Argentina ranged from $11.2 \pm 0.6$ to $25.8 \pm 0.9$ (Tosi et al., 2008). Diastase enzyme testing can also be used as an indicator of honey heating treatment (Purwanti, 2015). Diastase enzyme activity decreases when honey is heated at temperatures over $40^{\circ} \mathrm{C}$ (Purnamasari, 2015).

\subsection{Sugar level}

The main components of honey are water and sugar. The types of sugar found in honey are glucose and fructose, ranging from 70 to $80 \%$, while water is from 10 to $20 \%$ - other minor components identified as organic acid minerals, vitamins, enzymes, proteins, and volatile components. The reducing sugar content, which is considered glucose, has a minimum requirement of $65 \%$ (SNI 3545: 2013). The average glucose content in all forest honey samples from East Kalimantan is between $7.8 \%$ and $20.6 \%$ for fructose and between $1.2 \%$ and $18.7 \%$ (Table 1). In comparison, buckwheat honey from the USA had glucose content of $27-35 \%$ and fructose of 31-39\% (Pasini et al., 2013). The sugar content of manuka honey was $60.7 \mathrm{~g} / 100 \mathrm{~g}$ (Deng et al., 2018). Malaysian honey sugar content was $71.2 \mathrm{~g} / 100 \mathrm{~g}$ (Moniruzzaman et al., 2013). The amount of fructose and glucose in both manuka and Malaysian honey were higher than $60 \mathrm{~g} / 100 \mathrm{~g}$.
All honey samples, according to SNI standards (SNI 3545: 2013) fallen below the minimum level of reducing sugar of $65 \%$. Many factors cause sugar content in honey to decrease. Some of the factors that can affect the reducing sugar content of honey are moisture content, and when harvesting (Sudjatmiko, 2011). Unprocessed forest honey generally does not meet the SNI requirements of the water content of not more than $25 \%$ (Sartika, 2014).

\subsection{ABTS antioxidant levels}

Honey is flower pollen collected by bees. Therefore, honey's bioactive component depends on the type and quality of flowers that can be accessed by bees (AlBrahim and Mohammed, 2020). Naturally, flower extracts have many active compounds as a form of protection against natural conditions, parasites, and bacteria. Some active compounds in honey are then characterized as antioxidants. Components responsible for the presence of antioxidant effects on honey are flavonoids, catalases, phenolic acids, peroxidases, carotenoids, and non-peroxide compounds (Kamilatussaniah and Yuniastuti. 2016). For example, cardamom flowers contain hydroxycinnamic, aromatic antioxidants from the phenylpropanoid group (Pramitha et al., 2016). The antioxidant power found in flower extracts collected by bees depends on the antioxidant group and stereoisomer of the chemical compounds (Tanleque-Alberto et al., 2019). Some factors influence this antioxidant activity, including the source of interest used to produce nectar and environmental factors, including weather, climate, and processing (Tuksitha et al., 2018; Al-Brahim and Mohammed, 2020)

One of the honey that has the most potent antioxidant that had been studied was manuka honey from New Zealand (Deng et al., 2018). Forest honey from East Kalimantan has $\mathrm{IC}_{50}$ antioxidant levels ranging between $117.46 \pm 0.40$ and $584.13 \pm 3.20 \mathrm{ppm}$ (Table 1). 
The most potent antioxidant, or the lowest $\mathrm{IC}_{50}$ value, was found in MT2 forest honey, and the highest was in MK honey. Manuka honey had an $\mathrm{EC}_{50}$ antioxidant content of $82.4 \mathrm{mg} / \mathrm{mL}$ (Deng et al., 2018).

The antioxidant content of honey depends on nectar and phenolic compounds (Bertoncelj et al., 2007; Khalil et al., 2012). Antioxidant activity correlates with the color of honey. Darker honey colors tend to have higher phenolic and antioxidant compounds. (Tuksitha et al., 2018; Dżugan et al., 2020). MT2 forest honey has a darker color compared to other forest honey. Polyphenol compounds, flavonoids play an active role in the capture of free radicals and, in the body functions as an antioxidant, anti-inflammatory, inhibits the growth of microbes (Adawiah et al., 2015). Forest honey from East Kalimantan is expected to help maintain the immune system from the free radical attack.

\subsection{Antibacterial activity}

An antibacterial activity can be seen from the welling zone in the agar medium that has been dropped with honey. The clear area shows inhibitory activity against gram-positive and gram-negative bacteria. The effectiveness of inhibition on each test bacteria differs from one another depending on the type of honey and type of bacteria (Dżugan et al., 2020). Inhibitory zone diameters of all types of honey against $S$. aureus, $B$. cereus, E. coli, and $S$. enterica serovar Typhi bacteria can be seen in Table 2. Some other factors that influence differences in antibacterial activity are the age of honey and the suspension state of the test bacteria. Some honey showed vigorous antibacterial activity on Gram-positive bacteria. Some others had antibacterial activity on Gramnegative bacteria.

Forest honey from East Kalimantan has a resistance between 0.3 and $2.6 \mathrm{~mm}$ against $B$. cereus bacteria. The inhibition zone formed against the $S$. aureus bacteria is between 0.3 and $9.2 \mathrm{~mm}$. The inhibitory power for $E$. coli is between 0.1 and $8 \mathrm{~mm}$. for $S$. enterica serovar Typhi bacteria, the tasteless zone formed is between 0 and $2.6 \mathrm{~mm}$. The best inhibition is obtained from MT2 honey, which has inhibition of around $9.2 \mathrm{~mm}$ for $S$. aureus and $8 \mathrm{~mm}$ for E. coli. For the record, there is a sustainability problem of MT2 honey. This honey is obtained from forests in the Penajam Paser Utara area, in which the location is situated in the new Indonesian capital region. Other honey, which has good inhibition against bacteria, is MB5, which has inhibition of $7.1 \mathrm{~mm}$ against $S$. aureus and $7.4 \mathrm{~mm}$ against $E$. coli. This honey comes from Bongan, West Kutai Regency, East Kalimantan. Honey MT2 and MB5 had the highest activity among the honey samples studied. Some honey from Arabic had inhibitory zone activity against $E$. coli ranging between $5 \pm 0.6$ and $14.00 \pm 1.0 \mathrm{~mm}$ and against $S$. aureus ranging between $9.67 \pm 1.0$ and $20.33 \pm 2.1 \mathrm{~mm}$ (Ghramh et al., 2019)

The bacterial cell wall structure is the cause of differences in antibacterial responses (Anyanwu, 2011). Osmotic pressure, acidity, hydrogen peroxide, and phytochemical contents influence the antibacterial activity of honey. The minor antibacterial components included 3,4.5-trimethoxybenzoic acid, syringic acid, methyl syringic, terpenes, pinocembrin, and benzyl alcohol (Rahman et al., 2013). Honey from tropical forests of East Kalimantan has antibacterial activity caused by low $\mathrm{pH}$ and hydrogen peroxide.

\subsubsection{Minimum inhibitory concentration (MIC)}

Further testing of the antibacterial activity of honey MT2 and MB5 was carried out with the Minimum Inhibitory Concentration (MIC) technique for $S$. aureus and E. coli bacteria. The method of testing MIC is the same as testing antibacterial activity, but this test is conducted by setting some concentrations of honey to get

Table 2. Bacterial inhibition zone of East Kalimantan forest honey

\begin{tabular}{ccrcc}
\hline \multirow{2}{*}{ Honey } & \multicolumn{3}{c}{ Inhibition zone $(\mathrm{mm})$} \\
\cline { 2 - 5 } & \multicolumn{2}{c}{ Gram-positive $(+)$} & E. coli & Gram-negative (-) \\
\cline { 2 - 5 } MP1 & $2.6 \pm 0.22$ & $3.6 \pm 0.09$ & $7.9 \pm 0.13$ & S. enterica serovar Typhi \\
MT2 & $1.2 \pm 0.12$ & $9.2 \pm 0.15$ & $8.0 \pm 0.35$ & $1.6 \pm 0.21$ \\
MI3 & $2.0 \pm 0.06$ & $1.4 \pm 0.24$ & $5.6 \pm 0.28$ & $0.0 \pm 0.00$ \\
ML4 & $1.0 \pm 0.12$ & $2.5 \pm 0.29$ & $7.2 \pm 0.28$ & $0.0 \pm 0.00$ \\
MB5 & $0.3 \pm 0.14$ & $7.1 \pm 0.05$ & $7.4 \pm 0.38$ & $0.0 \pm 0.00$ \\
MLB6 & $0.0 \pm 0.00$ & $2.3 \pm 0.24$ & $5.3 \pm 0.25$ & $0.0 \pm 0.00$ \\
MBB7 & $0.3 \pm 0.14$ & $0.3 \pm 0.18$ & $2.8 \pm 0.20$ & $0.0 \pm 0.00$ \\
MMU8 & $0.0 \pm 0.00$ & $1.1 \pm 0.10$ & $0.1 \pm 0.13$ & $0.6 \pm 0.13$ \\
MLC9 & $0.5 \pm 0.17$ & $1.4 \pm 0.24$ & $5.3 \pm 0.24$ & $0.0 \pm 0.00$ \\
MK & $0.9 \pm 0.13$ & $2.0 \pm 0.08$ & $3.1 \pm 0.41$ & $0.0 \pm 0.00$ \\
\hline
\end{tabular}

Values expressed as mean $\pm \mathrm{SD}(\mathrm{n}=3)$. 
the lowest concentration that still shows inhibition of bacterial growth (Mandal et al., 2010)

The concentrations used in the MIC test in this study were $20 \%, 25 \%, 30 \%$, and $40 \%$. The concentration was obtained after several experiments (Table 3). It was reported that MT2 honey obtained a minimum inhibitory concentration of $2.7 \mathrm{~mm}$ at a concentration of $25 \%$, against $S$. aureus bacteria and $0.8 \mathrm{~mm}$ at a concentration of $25 \%$ against $E$. coli bacteria. In MB5 honey, MIC for $S$. aureus and E. coli bacteria was established at $30 \%$ honey concentration.

Table 3. MIC of forest honey against Gram-positive and Gram-negative bacteria

\begin{tabular}{lccc}
\hline \multirow{2}{*}{ Honey } & \multirow{2}{*}{ Concentration } & \multicolumn{2}{c}{ Inhibition zone $(\mathrm{mm})$} \\
& & S. aureus & E.coli \\
\hline MT2 & MT2 40\% & $5.2 \pm 0.25$ & $3.5 \pm 0.61$ \\
& MT2 30\% & $3.7 \pm 0.26$ & $1.4 \pm 0.12$ \\
& MT2 25\% & $2.7 \pm 0.25$ & $0.8 \pm 0.29$ \\
& MT2 20\% & $0.0 \pm 0.00$ & $0.0 \pm 0.00$ \\
\hline MB5 & MB5 40\% & $3.1 \pm 0.17$ & $1.2 \pm 0.29$ \\
& MB5 30\% & $2.0 \pm 0.06$ & $0.5 \pm 0.06$ \\
& MB5 25\% & $0.0 \pm 0.00$ & $0.0 \pm 0.00$ \\
& MB5 20\% & $0.0 \pm 0.00$ & $0.0 \pm 0.00$ \\
\hline
\end{tabular}

Values are expressed as mean $\pm \mathrm{SD}(\mathrm{n}=3)$

Similar research has also been carried out by (Voidarou et al., 2011; Packer et al., 2012). The minimum concentration against $P$. aeruginosa bacteria of Heather honey, Manuka honey, and Khadikraft honey was $10 \%$. Local honey has inhibition of $11 \%$ to the respective bacteria. Buckwheat honey from the USA was effective against Gram-positive bacteria. From the research results obtained, MIC values of 15 and $20 \%$ respectively for $S$. aureus. In Ethiopian wheat honey, MIC was higher observed for $K$. pneumoniae than $S$. aureus and E. coli (Hammond et al., 2016). Research (Dżugan et al., 2020) Buckwheat honey has a minimum inhibitory level in $S$. aureus and E. coli bacteria by $25 \%$.
Based on the above comparison, Kalimantan forest honey has the same minimum inhibition potential as Polish buckwheat honey.

\subsubsection{Honey antibacterial potential compared with chloramphenicol antibiotics}

The results of testing the antibacterial activity were compared with those of the $30 \mu \mathrm{g} / \mathrm{mL}$ chloramphenicol antibiotic (Table 4). Furthermore, these results were calculated by comparing the percent inhibition of honey against antibiotics. The percent inhibition of honey varies between $1 \%$ and $46 \%$ in all types of bacteria and honey types. MT2 honey has the highest inhibition of $46 \%$ equivalent to $13.86 \mu \mathrm{g}$ chloramphenicol against $S$. aureus bacteria and 39\% against $E$. coli bacteria. MB5 honey has $36 \%$ inhibition, equivalent to $11.76 \mu \mathrm{g}$ chloramphenicol against $S$. aureus and E. coli. Other researchers report that $1 \mathrm{~mL}$ of bitter honey $\mathrm{C}$ and $\mathrm{D}$ were equal to 21.87 and $18.38 \mu \mathrm{g}$ chloramphenicol (Astrini, 2014). It was concluded that East Kalimantan tropical forest honey had lower inhibition compared to other commercial bitter honey. The more moderate antibacterial content is due to the high moisture content of East Kalimantan tropical forest honey.

\subsection{Analysis of honey antibacterial functional group}

The mechanism of honey as an antibacterial can be classified directly in the presence of hydrogen peroxide $\left(\mathrm{H}_{2} \mathrm{O}_{2}\right)$ (Adawiah et al., 2015). Hydrogen peroxide is a substance sensitive to heat and light, and beekeeping methods and storage conditions influence the content of $\mathrm{H}_{2} \mathrm{O}_{2}$ (Dżugan et al., 2020). One quick way to detect $\mathrm{H}_{2} \mathrm{O}_{2}$ is to use the FTIR instrument and compare the reading results against the $\mathrm{H}_{2} \mathrm{O}_{2}$ standard (Table 5).

Before discussing the confirmation of the presence of $\mathrm{H}_{2} \mathrm{O}_{2}$, all honey samples have similar functional group peaks (Figure 1). Absorption widens at the wavenumber between 3251.62 and $3269.84 \mathrm{~cm}^{-1}$, where $\mathrm{O}-\mathrm{H}$

Table 4. Comparison of percentage inhibition to chloramphenicol antibiotics

\begin{tabular}{|c|c|c|c|c|}
\hline \multirow{3}{*}{ Honey } & \multicolumn{4}{|c|}{ percentage inhibition compared to $30 \mu \mathrm{g} / \mathrm{mL}$ chloramphenicol } \\
\hline & \multicolumn{2}{|c|}{ Gram-positive $(+)$} & \multicolumn{2}{|c|}{ Gram-negative (-) } \\
\hline & S. aureus & B. cereus & E. coli & S. enterica serovar Typhi \\
\hline MP1 & $18.18 \pm 0.92$ & $12.26 \pm 2.13$ & $38.60 \pm 1.23$ & $15.70 \pm 2.56$ \\
\hline MT2 & $46.21 \pm 1.52$ & $5.65 \pm 1.14$ & $39.22 \pm 3.47$ & $6.86 \pm 1.52$ \\
\hline MI3 & $6.94 \pm 2.42$ & $9.74 \pm 0.60$ & $27.57 \pm 2.78$ & $0.00 \pm 0.00$ \\
\hline ML4 & $12.50 \pm 2.96$ & $4.81 \pm 1.18$ & $35.17 \pm 2.78$ & $0.00 \pm 0.00$ \\
\hline MB5 & $35.61 \pm 0.51$ & $1.20 \pm 1.39$ & $36.15 \pm 3.68$ & $0.00 \pm 0.00$ \\
\hline MLB6 & $11.62 \pm 2.40$ & $0.00 \pm 0.00$ & $25.74 \pm 2.45$ & $0.00 \pm 0.00$ \\
\hline MBB7 & $1.52 \pm 1.80$ & $1.20 \pm 1.39$ & $13.73 \pm 1.96$ & $0.00 \pm 0.00$ \\
\hline MMU8 & $5.56 \pm 1.01$ & $0.00 \pm 0.00$ & $0.61 \pm 1.23$ & $3.81 \pm 1.52$ \\
\hline MLC9 & $7.07 \pm 2.47$ & $2.28 \pm 1.64$ & $26.10 \pm 2.31$ & $0.00 \pm 0.00$ \\
\hline MP1 & $10.10 \pm 0.82$ & $4.21 \pm 1.20$ & $14.95 \pm 4.03$ & $0.00 \pm 0.00$ \\
\hline
\end{tabular}

Values expressed as mean \pm SD $(n=3)$. 
Table 5. Comparison of FTIR spectra of East Kalimantan forest honey and hydrogen peroxide

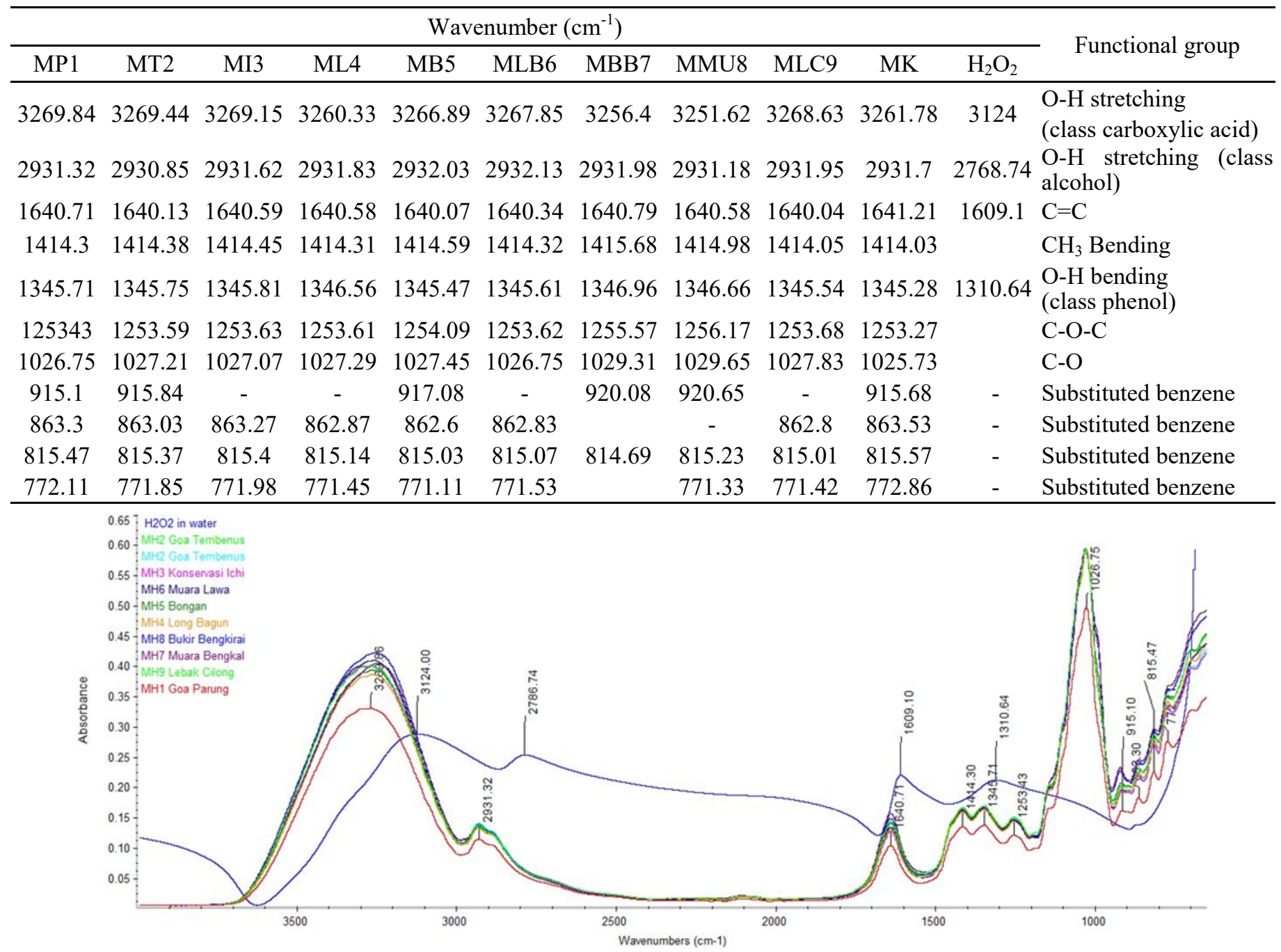

Figure 1. All spectrum of Honey compared with $\mathrm{H}_{2} \mathrm{O}_{2}$ standard

vibrations occur (Table 5). Aliphatic $\mathrm{C}-\mathrm{H}$ vibrations in honey were detected at wavenumbers between 2930.85 and $2932.13 \mathrm{~cm}^{-1}$. The $\mathrm{C}=\mathrm{C}$ honey function group exposed from the wavenumber between 1640.13 and $1641.21 \mathrm{~cm}^{-1}$. The peak wavenumber between 1414.3 and $1414.98 \mathrm{~cm}^{-1}$ was identified as $\mathrm{CH}_{3}$. Vibrations of C$\mathrm{O}$ compounds identified as peaks at wavenumbers between 1026.75 and $1029.65 \mathrm{~cm}^{-1}$. The next peak was the aromatic ring substitution detected in the wavenumber between 920.08 and $771.33 \mathrm{~cm}^{-1}$ (Table 5). From the results of FTIR spectrum readings, functional groups $\mathrm{OH}, \mathrm{CH}$ aliphatic, $\mathrm{C}=\mathrm{C}, \mathrm{CH}_{3}, \mathrm{CO}, \mathrm{C}-\mathrm{O}-\mathrm{C}$, and several aromatic rings identified in the honey from tropical forests of East Kalimantan.

Concerning $\mathrm{H}_{2} \mathrm{O}_{2}$ standard, all honey from tropical forests in East Kalimantan shows the presence of functional groups $\mathrm{O}-\mathrm{H}$ stretching (class carboxylic acid), $\mathrm{O}-\mathrm{H}$ stretching (class alcohol), and $\mathrm{O}-\mathrm{H}$ bending (class phenol). Hydrogen peroxide and some non-peroxide components were the antibacterial properties of Polish and Canadian buckwheat honey (Brudzynski et al., 2012; Sowa et al., 2017).

\section{Conclusion}

Forest honey originating from several areas of East Kalimantan forest has different diastase enzyme levels, water levels, $\mathrm{pH}$ levels, sugar, antibacterial, and antioxidant content. However, the profile of FTIR and forest honey tends to be the same. MT2 honey has high antioxidant activity with $\mathrm{IC}_{50}$ values of $117.46 \pm 0.40$ ppm. MT2 and MB5 honey had antibacterial activity against $S$. aureus and $E$. coli with clear zone diameters of $9.2 \pm 0.15$ and $8.0 \pm 0.35 \mathrm{~mm}$ for MT2 honey and $7.1 \pm 0.05$ and $7.4 \pm 0.38 \mathrm{~mm}$ for MB5 honey. Minimum inhibitory levels for Gram-negative and positive test bacteria were in the range of $25 \%$ honey concentration for MT2 honey and $30 \%$ for MB5 honey. The antimicrobial activity of 1 $\mathrm{mL}$ MT2 honey was equivalent to $13.86 \mu \mathrm{g}$ chloramphenicol for the $S$. aureus test bacteria. The activity of $1 \mathrm{~mL}$ MT2 honey was equivalent to $11.76 \mu \mathrm{g}$ chloramphenicol for E. coli test bacteria. The FTIR pattern showed that all honey samples have the same leading functional group as the $\mathrm{H}_{2} \mathrm{O}_{2}$ standard.

\section{Conflict of interest}

We declare that we do not have a conflict of interest. 


\section{Acknowledgments}

Toray Indonesia funded this research in 2020.

\section{References}

Adalina, Y. (2017). Kualitas Madu Putih Asal Provinsi Nusa Tenggara Barat. Prosiding Seminar Nasional Masyarakat Biodiversitas Indonesia, 3(2), 189-193. [In Bahasa Indonesia]. https://doi.org/10.13057/ psnmbi/m030204

Al-Brahim, J.S. and Mohammed, A.E. (2020). Antioxidant, cytotoxic, and antibacterial potential of biosynthesized nanoparticles using bee honey from two different floral sources in Saudi Arabia. Saudi Journal of Biological Sciences, 27(1), 363-373. https://doi.org/10.1016/j.sjbs.2019.10.006

Alzahrani, H.A., Alsabehi, R., Boukraâ, L., Abdellah, F., Bellik, Y. and Bakhotmah, B.A. (2012). Antibacterial and antioxidant potency of floral honeys from different botanical and geographical origins. Molecules, 17(9), 10540-10549. https:// doi.org/10.3390/molecules

Anyanwu, C. (2011). Assessment of the in vitro antibacterial activity of honey on some common human pathogens. Journal of Research in Biology, 2, 116-121.

Astrini. D. (2014). Aktivitas antibakteri madu pahit terhadap bakteri gram negatif dan gram positif serta potensinya dibandingkan terhadap antibiotik kloramfenikol, oksitetrasiklin dan gentamisin. Acta Pharmaceutica Indonesia, 39(3 and 4), 75-83. [In Bahasa Indonesia].

Bentabol Manzanares, A., Hernández García, Z., Rodríguez Galdón, B., Rodríguez Rodríguez, E. and Díaz Romero, C. (2014). Physicochemical characteristics of minor monofloral honeys from tenerife, spain. LWT-Food Science and Technology, 55(2), 572-578. https://doi.org/10.1016/ j.lwt.2013.09.024

Bertoncelj, J., Dobersek, U., Jamnik, M. and Golob, T. (2007). Evaluation of the phenolic content, antioxidant activity, and color of Slovenian honey. Food Chemistry, 105(2), 822-828. https:// doi.org/10.1016/j.foodchem.2007.01.060

Brudzynski, K., Abubaker, K. and Wang, T. (2012). Powerful bacterial killing by Buckwheat honeys is concentration-dependent, involves complete DNA degradation, and requires hydrogen peroxide. Frontiers in Microbiology, 3, 242. https:// doi.org/10.3389/fmicb.2012.00242

Codex Alimentarius Commission (CAC). (2001). Revised Standards for Honey. Codex Standard 121981. Retrieved on May 5, 2020, from FAO Website: http://www.fao.org/input/download/ standards/310/cxs_012e.pdf

Da Silva, P.M., Gauche, C., Gonzaga, L.V., Costa, A.C.O. and Fett, R. (2016). Honey: chemical composition, stability, and authenticity. Food Chemistry, 196, 309-323. https://doi.org/10.1016/ j.foodchem.2015.09.051

Deng, J., Liu, R., Lu, Q., Hao, P., Xu, A., Zhang, J. and Tan, J. (2018). Biochemical properties, antibacterial, and cellular antioxidant activities of buckwheat honey in comparison to manuka honey. Food Chemistry, 252, 243-249. https://doi.org/10.1016/ j.foodchem.2018.01.115

Dżugan, M., Grabek-Lejko, D., Swacha, S., Tomczyk, M., Bednarska, S. and Kapusta, I. (2020). Physicochemical quality parameters, antibacterial properties, and cellular antioxidant activity of polish buckwheat honey. Food Bioscience, 34, 100538. https://doi.org/10.1016/j.fbio.2020.100538

Fazriyanti, N. (2015). Pengaruh perbedaan konsentrasi madu dan lama fermentasi terhadap $\mathrm{pH}$, total asam, gula reduksi dan potensi antibakteri kefir air leri. Malang, Indonesia: Universitas Islam Negeri (UIN) Maulana Malik Ibrahim Malang, MSc. Thesis. [In Bahasa Indonesia].

Ghramh, H.A., Khan, K.A. and Alshehri, A.M.A. (2019). Antibacterial potential of some Saudi honeys from Asir region against selected pathogenic bacteria. Saudi Journal of Biological Sciences, 26(6), 12781284. https://doi.org/10.1016/j.sjbs.2018.05.011

Hammond, E.N.-A., Duster, M., Musuuza, J.S. and Safdar, N. (2016). Effect of United States buckwheat honey on antibiotic-resistant hospital-acquired pathogens. Pan African Medical Journal, 25, 212. https://doi.org/10.11604/pamj.2016.25.212.10414

Heard, M.S., Baas, J., Dorne, J.-L., Lahive, E., Robinson, A.G., Rortais, A., Spurgeon, D.J., Svendsen, C. and Hesketh, H. (2017). Comparative Toxicity Of Pesticides And Environmental Contaminants In Bees: Are Honey Bees A Useful Proxy For Wild Bee Species?. Science of The Total Environment, 578, 357-365. https://doi.org/10.1016/ j.scitotenv.2016.10.180

Irnawati, Riyanto, S., Martono, S. and Rohman, A. (2020) Kerja dengan spektroskopi FTIR dan kemometrika untuk otentikasi minyak biji labu dari minyak wijen. Yogyakarta, Indoensia: Departemen Farmasi Kimia, Fakultas Farmasi, Universitas Gadjah Mada. [In Bahasa Indonesia].

Khalil, M.I., Moniruzzaman, M., Boukraâ, L., Benhanifia, M., Islam, M.A., Islam, M.N., Sulaiman, S.A. and Gan, S.H. (2012). Physicochemical and Antioxidant Properties of Algerian Honey. 
Molecules, 17(9), 11199-11215. https:// doi.org/10.3390/molecules170911199

Kamilatussaniah, A. and Yuniastuti, R.I. (2016). Pengaruh Suplementasi Madu Kelengkeng Terhadap Kadar Tsa Dan Mda Tikus Putih Yang Diinduksi Timbal (Pb). Jurnal Mipa, 38(2), 108-114. [In Bahasa Indonesia].

Salampe, M., Rahma, Z., Nur, S. and Mamada S.S. (2019). Aktivitas antioksidan ekstrak etanol daun beroma (Cajanus cajan (L.) Milps). Majalah Farmasi Dan Farmakologi, 23(1), 9-31. [In Bahasa Indonesia]. https://doi.org/10.20956/mff.v23i1.6464

Mandal, S., Debmandal, M., Pal, N.K. and Saha, K. (2010). Antibacterial activity of honey against clinical isolates of Escherichia coli, Pseudomonas aeruginosa, and Salmonella enterica Serovar typhi. Asian Pacific Journal of Tropical Medicine, 3(12), 961-964. https://doi.org/10.1016/S1995-7645(11) 60009-6

Moniruzzaman, M., Sulaiman, S.A., Khalil, I. and Gan, S.H. (2013). Evaluation of physicochemical and antioxidant properties of sour and other Malaysian honeys a comparison with manuka honey. Chemistry Central Journal, 7, 138. https://doi.org/10.1186/1752 $-153 \mathrm{X}-7-138$

Muslim, T. (2014). Potensi Madu Hutan Dan Pengelolaannya Di Indonesia-In Tumbuhan Obat Dari Hutan: Konservasi, Budidaya Dan Pemanfaatan presented at Seminar Balitek KSDA. Balikpapan, Indonesia. [In Bahasa Indonesia].

Pasini, F., Gardini, S., Marcazzan, G.L. and Caboni, M.F. (2013). Buckwheat honeys: Screening of composition and properties. Food Chemistry, 141(3), 2802-2811.

j.foodchem.2013.05.102

Packer, J.M., Irish, J., Herbert, B.R., Hill, C., Padula, M., Blair, S.E., Carter, D.A. and Harry, E.J. (2012). Specific Non-Peroxide Antibacterial Effect of Manuka Honey on The Staphylococcus aureus Proteome. International Journal of Antimicrobial Agents, 40(1), 43-50. https://doi.org/10.1016/ j.ijantimicag.2012.03.012

Pramitha, C.P., Aminah, N.S. and Kristanti, A.N. (2016). Skopoletin senyawa fenilpropanoid dari kulit umbi ubi jalar (Ipomoea batatas L.) varietas Ir-Melati. Jurnal Kimia Riset, 1(2), 81. [In Bahasa Indonesia]. https://doi.org/10.20473/jkr.v1i2.3087

Purwanti, A.C. (2015). Pengaruh Suhu Dan Ph Terhadap Aktivitas Enzim Xilanase Dari Trichoderma Viride Yang Ditumbuhkan Pada Media Tongkol Jagung. Malang, Indonesia: Univerisitas Islam Negeri Maulana Malik Ibrahim, BSc. Thesis. [In Bahasa
Indonesia].

Purnamasari, N., Aprilia, H. and Sukanta. (2015). Pembandingan parameter fisikokimia madu pahit (aktivitas enzim diastase, gula pereduksi (glukosa), keasaman, dan cemaran abu dan arsen) dengan madu manis murni. Prosiding Penelitian SPeSIA, 1(1), 4650. [In Bahasa Indonesia].

Rachmawaty, M. (2011). Efektivitas Beberapa Uji Pemalsuan Madu Kapuk. Bogor: Institut Pertanian Bogor, MSc. Thesis. [In Bahasa Indonesia].

Rahman, K., Hussain, A., Ullah, S., Ullah, I. and Zai, M. (2013). Phytochemical Analysis and Chemical Composition of Different Branded And Unbranded Honey Samples. International Journal of Microbiological Research, 4(2), 132-137. Https:// Doi.Org/10.5829/Idosi.Ijmr.2013.4.2.1103

Sartika. (2011). Analisis Kadar Glukosa Dan Fruktosa Pada Beberapa Madu Murni Yang Beredar Di Pasaran Dengan Menggunakan Metode Spektrofotometri Visibel. Makassar, Indonesia: Universitas Islam Negeri Alauddin Makassar, MSc. Thesis. [In Bahasa Indonesia].

Sofia, Zainal, S. and Roslinda, E. (2017). Pengelolaan madu hutan berbasis kearifan lokal masyarakat di desa semalah dan desa melemba kawasan danau sentarum, Kabupaten Kapuas Hulu. Jurnal Hutan Lestari, 5(2), 209-218. [In Bahasa Indonesia].

Sowa, P., Grabek-Lejko, D., Wesołowska, M., Swacha, S. and Dżugan, M. (2017). Hydrogen peroxidedependent antibacterial action of Melilotus albus honey. Letters in Applied Microbiology, 65(1), 8289. https://doi.org/10.1111/lam.12749

Sudarmadji, S., Haryono, B. and Suhardi. (2010). Prosedur Analisa Untuk Bahan Makanan dan Pertanian. Yogyakarta: Liberty. [In Bahasa Indonesia].

Sudjatmiko, G. (2011). Madu untuk obat luka kronis, p. 7-31. Jakarta: Yayasan Khasanah Kebajikan. [In Bahasa Indonesia].

Tanleque-Alberto, F., Juan-Borrás, M. and Escriche, I. (2019). Quality parameters, pollen, and volatile profiles of honey from North and Central Mozambique. Food Chemistry, 277, 543-553. https://doi.org/10.1016/j.foodchem.2018.11.007

Tosi, E., Martinet, R., Ortega, M., Lucero, H. and Ré, E. (2008). Honey diastase activity modified by heating. Food Chemistry, 106(3), 883-887. https:// doi.org/10.1016/j.foodchem.2007.04.025

Tuksitha, L., Chen, Y.L.S., Chen, Y.L., Wong, K.Y. and Peng, C.C. (2018). Antioxidant and antibacterial capacity of stingless bee honey from Borneo (Sarawak). Journal of Asia-Pacific Entomology, 21 
(2), 563-570. https://doi.org/10.1016/ j.aspen.2018.03.007

Voidarou, C., Alexopoulos, A., Plessas, S., Karapanou, A., Mantzourani, I., Stavropoulou, E., Fotou, K., Tzora, A., Skoufos, I. and Bezirtzoglou, E. (2011). Antibacterial Activity of Different Honeys Against Pathogenic Bacteria. Anaerobe, 17(6), 375-379. https://doi.org/10.1016/j.anaerobe.2011.03.012

Wulandari, D.D. (2017). Kualitas madu (keasaman, kadar air, dan kadar gula pereduksi) berdasarkan perbedaan suhu penyimpanan. Jurnal Kimia Riset, 2 (1), 16-22. [In Bahasa Indonesia]. https:// doi.org/10.20473/jkr.v2i1.3768 